\title{
The assessment of oesophagitis in hiatus hernia patients
}

\author{
A. S. WAR D, D. H. WR IGH T, and J. LEIGH COLLIS 1 \\ Queen Elizabeth Hospital, Edgbaston, Birmingham, and Department of Pathology, \\ The Medical School, Birmingham
}

\begin{abstract}
The incidence of oesophagitis has been determined in 108 patients with sliding hiatus hernias using endoscopic, histological, and radiological criteria. Particular consideration has been given to the relationship between inflammatory disease and clinical symptoms. All the patients were attending a thoracic surgical clinic and the spectrum of disease encountered was fairly severe; over half of the cases had established strictures when first seen. The incidence of oesophagitis based on endoscopic evidence was $76.9 \%$, while inflammatory change was noted on biopsy in $56.2 \%$ and at barium swallow in $58.3 \%$ of the patients. Oesophagoscopy proved to be the most satisfactory method of assessment; biopsy specimens were either inadequate or correlated poorly with other criteria while barium swallow was of diagnostic value only in severe oesophagitis. The main symptoms were pain, heartburn with regurgitation, dysphagia, and bleeding. Dysphagia was common due to the preponderance of patients with strictures, while obvious bleeding was very uncommon. Endoscopic oesophagitis was found in $75 \%$ of the patients with specific retrosternal pain and in $60 \%$ of those with heartburn and regurgitation. The inability to equate heartburn with oesophagitis is emphasized. The incidence of inflammatory change in patients with dysphagia was $87.2 \%$; nearly all the cases in this group showed stricture formation.
\end{abstract}

Gastro-oesophageal reflux occurs in most patients with symptomatic hiatus hernia and may produce an inflammatory reaction of varying severity in the lower oesophagus. 'There is no agreement, however, on the frequency with which this reaction occurs nor on the influence it may have on clinical symptoms. In the past, many of the symptoms in hiatus hernia patients have been loosely attributed to reflux oesophagitis without adequate objective evidence. This study was undertaken firstly to determine the incidence of oesophagitis according to endoscopy, biopsy, and radiological examination, secondly to correlate this evidence with clinical symptoms, and thirdly to evaluate the merit of the individual means of assessment.

\section{MATERIAL AND METHODS}

One hundred and eight patients with sliding hiatus hernias seen between January 1966 and December 1969 were studied. Symptoms were sufficiently troublesome in all cases to warrant referral for surgical advice and in this respect the group is somewhat selective. There were 55 men and 53 women, with a mean age of 59 years (range 33-82 years). Particular attention was paid to four symptoms - namely, pain, heartburn with or without acid regurgitation, dysphagia, and bleeding. Pain was considered to be due to oesophagitis if it 'Requests for reprints to J.L.C. was retrosternal, of burning quality and brought on by meals or by stooping or lying flat. Discomfort on swallowing, particularly with hot tea or alcohol, and relief by antacids were features particularly suggestive of oesophagitis. Heartburn was defined as a retrosternal pain of a more diffuse type with radiation to the neck. Acid regurgitation into the throat was a usual accompaniment and both symptoms were precipitated by recumbency and food. There were no special features in the interpretation of dysphagia and bleeding.

Barium swallow was performed in most patients by one radiologist with a special interest in the oesophagus. Standard techniques were used to demonstrate reflux, stricture formation and ulceration. The stomach and duodenum were closely examined to exclude other lesions such as peptic ulceration or pyloric stenosis.

Oesophagoscopy was performed in all cases by one $\mathcal{O}$ of us (J. L.C.), using an Irwin Moore oesophagoscope. N Inflammatory changes were graded as follows: N A, mild oesophagitis - a reddening of the mucosa; $\omega$ B, moderate oesophagitis - a red mucosa which bled 2 easily as a result of mild trauma ; C. severe oeso- 0 phagitis - ulceration often with spontaneous bleeding, stricture or membrane formation.

Biopsies were taken from the most severely 0 affected areas or from the lower $4 \mathrm{~cm}$. of oesophagus ${ }^{D}$ when no obvious inflammation was present. Patterson $\mathbb{8}$ extra fine biopsy forceps were used for this purpose. $\mathbb{\mathbb { D }}$ Histological changes were graded as follows: 
I, normal or minimal oesophagitis--scanty infiltrate of lymphocytes and plasma cells in the lamina propria ; II, moderate oesophagitis-presence of polymorphs as well as lymphocytes and plasma cells in the lamina propria ; III, severe oesophagitis-marked cellular infiltrate with ulceration. A small number of cases were placed in intermediate grades.

\section{RESULTS}

The incidence of oesophagitis based on oesophagoscopy, biopsy, and radiological examination is shown in Table I. Oesophagoscopy demonstrated inflammatory change in 83 patients (76.9\%) and

\section{T A B L E I}

OESOPHAGOSCOPY, BIOPSY, AND RADIOLOGICAL FIND. INGS IN 108 PATIENTS WITH SLIDING HIATUS HERNIA

\begin{tabular}{|c|c|c|c|c|c|}
\hline \multicolumn{2}{|c|}{ Oesophagoscopy } & \multicolumn{2}{|c|}{ Biopsy $^{1}$} & \multicolumn{2}{|c|}{ Radiology } \\
\hline Grade & $\begin{array}{l}\text { No. } \\
\text { of } \\
\text { Pat- } \\
\text { ients }\end{array}$ & Grade & $\begin{array}{l}\text { No. } \\
\text { of } \\
\text { Pat- } \\
\text { ients }\end{array}$ & Findings & $\begin{array}{c}\text { No. } \\
\text { of } \\
\text { Pat- } \\
\text { ients }\end{array}$ \\
\hline Nil & 25 & $\mathbf{I}$ & 32 & $\begin{array}{l}\text { Sliding hiatus } \\
\text { hernia with }\end{array}$ & 45 \\
\hline$\stackrel{\mathbf{A}}{\mathbf{B}}$ & $\begin{array}{r}15 \\
6\end{array}$ & $\begin{array}{l}\text { I-II } \\
\text { II }\end{array}$ & $\begin{array}{l}8 \\
9\end{array}$ & $\begin{array}{l}\text { Stricture } \\
\text { Stricture + }\end{array}$ & $\begin{array}{r}53 \\
6\end{array}$ \\
\hline C Stricture & 54 & II-III & 5 & Ulcer & 2 \\
\hline $\begin{array}{r}\text { Stricture } \\
\text { +ulcer }\end{array}$ & 7 & III & 19 & Mucosal & 2 \\
\hline Ulcer & 1 & & & & \\
\hline $\begin{array}{l}\text { Total with } \\
\text { oeso- } \\
\text { phagitis }\end{array}$ & 83 & $\begin{array}{l}\text { Total with } \\
\text { oeso- } \\
\text { phagitis }\end{array}$ & 41 & $\begin{array}{l}\text { Total with } \\
\text { oeso- } \\
\text { phagitis }\end{array}$ & 63 \\
\hline $\begin{array}{c}\text { Percentage } \\
\text { oeso- } \\
\text { phagitis }\end{array}$ & 76.9 & $\begin{array}{l}\text { Percentage } \\
\text { oeso- } \\
\text { phagitis }\end{array}$ & $56 \cdot 2$ & $\begin{array}{l}\text { Percentage } \\
\text { oeso- } \\
\text { phagitis }\end{array}$ & $58 \cdot 3$ \\
\hline
\end{tabular}

173 adequate biopsies

in the majority this change was severe. An adequate biopsy was obtained in 73 patients, of whom $41(56.2 \%)$ showed histological inflammation. The inflammatory reaction was again severe in most cases. Oesophagitis was detected on radiological examination in 63 patients (58.3\%) ; stricture formation accounted for all except four of these cases.

The endoscopy, biopsy, and radiological findings have been related to each of four main symptoms.

1. Pain. This is an important feature in 32 patients (Table II). Specific pain was thought to be due to oesophagitis, and endoscopic evidence of inflammation was found in 24 cases $(75 \%)$. Histological changes were noted in 11 out of 23 adequate biopsies $(47.8 \%)$ and a diagnosis of oesophagitis was made in 13 patients $(40.6 \%)$ on barium swallow. There were eight patients with pain but no evidence of oesophagitis at endoscopy
T A B L E I I

OESOPHAGOSCOPY, BIOPSY, AND RADIOLOGICAL FINDINGS IN 32 PATIENTS WITH RETROSTERNAL PAIN

\begin{tabular}{|c|c|c|c|c|c|}
\hline \multicolumn{2}{|c|}{ Oesophagoscopy } & \multicolumn{2}{|c|}{ Biopsy'1 } & \multicolumn{2}{|c|}{ Radiology } \\
\hline Grade & $\begin{array}{l}\text { No. } \\
\text { of } \\
\text { Pat- } \\
\text { ients }\end{array}$ & Grade & $\begin{array}{c}\text { No. } \\
\text { of } \\
\text { Pat- } \\
\text { ients }\end{array}$ & Findings & $\begin{array}{c}\text { No. } \\
\text { of } \\
\text { Pat- } \\
\text { ients }\end{array}$ \\
\hline Nil & 8 & I & 12 & $\begin{array}{l}\text { Hernia with } \\
\text { reflux }\end{array}$ & 19 \\
\hline $\mathbf{A}$ & 8 & I-II & 3 & $\begin{array}{l}\text { renux } \\
\text { Stricture }\end{array}$ & 9 \\
\hline B & 3 & II-III & 0 & Stricture + & 2 \\
\hline C & 13 & III & 6 & $\begin{array}{l}\text { Ulcer } \\
\text { Mucosal } \\
\text { irregularity }\end{array}$ & $\begin{array}{l}1 \\
1\end{array}$ \\
\hline $\begin{array}{l}\text { Total with } \\
\text { oeso- } \\
\text { phagitis }\end{array}$ & 24 & $\begin{array}{l}\text { Total with } \\
\text { oeso- } \\
\text { phagitis }\end{array}$ & 11 & $\begin{array}{l}\text { Total with } \\
\text { oeso- } \\
\text { phagitis }\end{array}$ & 13 \\
\hline $\begin{array}{l}\text { Percentage } \\
\text { oeso- } \\
\text { phagitis }\end{array}$ & 75 & $\begin{array}{c}\text { Percentage } \\
\text { oeso- } \\
\text { phagitis }\end{array}$ & $47 \cdot 8$ & $\begin{array}{c}\text { Percentage } \\
\text { oeso- } \\
\text { phagitis }\end{array}$ & $40 \cdot 6$ \\
\hline
\end{tabular}

123 adequte biopsies

or radiologically. Oesophageal biopsy was normal in six of these cases and two showed histological inflammatory change.

2. Heartburn and regurgitation. Thirty-five patients complained of heartburn and regurgitation (Table III). Oesophagitis was found at endo-

T A B L E I I I

OESOPHAGOSCOPY, BIOPSY, AND RADIOLOGICAL FINDINGS IN 35 PATIENTS WITH HEARTBURN AND REGURGITATION

\begin{tabular}{|c|c|c|c|c|c|c|}
\hline \multicolumn{3}{|c|}{ Oesophagoscopy } & \multicolumn{2}{|c|}{ Biopsy } & \multicolumn{2}{|c|}{ Radiology } \\
\hline \multicolumn{2}{|c|}{ Grade } & $\begin{array}{l}\text { No. of } \\
\text { Patients }\end{array}$ & Grade & $\begin{array}{l}\text { No. of } \\
\text { Patients }\end{array}$ & Findings & $\begin{array}{l}\text { No. of } \\
\text { Patients }\end{array}$ \\
\hline Nil & $\cdots$ & 14 & & 12 & $\begin{array}{l}\text { Hernia } \\
\text { with reflux }\end{array}$ & 26 \\
\hline $\begin{array}{l}\mathbf{A} \\
\mathbf{B}\end{array}$ & $\begin{array}{l}\cdots \\
\cdots\end{array}$ & $\begin{array}{l}7 \\
2\end{array}$ & II-II & $\begin{array}{l}2 \\
4\end{array}$ & $\begin{array}{l}\text { Stricture } \\
\text { Stricture }+\end{array}$ & 7 \\
\hline C & . & 12 & $\begin{array}{l}\text { II-III } \\
\text { III }\end{array}$ & $\begin{array}{l}2 \\
4\end{array}$ & $\begin{array}{l}\text { ulcer } \\
\text { Ulcer } \\
\text { Mucosal } \\
\text { irregularity }\end{array}$ & $\begin{array}{l}2 \\
0 \\
0\end{array}$ \\
\hline $\begin{array}{l}\text { Tot } \\
\text { oes }\end{array}$ & $\begin{array}{l}\text { ith } \\
\text { agitis }\end{array}$ & 21 & $\begin{array}{c}\text { Total with } \\
\text { oesophagitis }\end{array}$ & 12 & $\begin{array}{l}\text { Total with } \\
\text { oesophagitis }\end{array}$ & 9 \\
\hline $\begin{array}{l}\text { Perc } \\
\text { oes }\end{array}$ & $\begin{array}{l}\text { ge } \\
\text { gitis }\end{array}$ & 60 & $\begin{array}{l}\text { Percentage } \\
\text { oesophagitis }\end{array}$ & 50 & $\begin{array}{l}\text { Percentage } \\
\text { oesophagitis }\end{array}$ & $25 \cdot 7$ \\
\hline
\end{tabular}

124 adequate biopsies

scopy in 21 cases $(60 \%)$ and histological inflammation was evident in 12 out of 24 adequate biopsies $(50 \%)$. Barium swallow demonstrated inflammatory change in nine patients $(25.7 \%)$, all of whom had positive findings at endoscopy.

3. Dysphagia. This was present in 78 patients and was thus the commonest symptom in the entire series (Table IV). Oesophagitis was evident at endoscopy in 68 patients $(87.2 \%)$, histological evidence of inflammation was present in 32 out 
T A B L E I V

OESOPHAGOSCOPY, BIOPSY, AND RADIOLOGICAL FINDINGS IN 78 PATIENTS WITH DYSPHAGIA

\begin{tabular}{|c|c|c|c|c|c|}
\hline \multicolumn{2}{|c|}{ Oesophagoscopy } & \multicolumn{2}{|c|}{ Biopsy ${ }^{1}$} & \multicolumn{2}{|c|}{ Radiology } \\
\hline Grade & $\begin{array}{l}\text { No. } \\
\text { of } \\
\text { Pat- } \\
\text { ients }\end{array}$ & Grade & $\begin{array}{c}\text { No. } \\
\text { of } \\
\text { Pat- } \\
\text { ients }\end{array}$ & Grade & $\begin{array}{l}\text { No. } \\
\text { of } \\
\text { Pat- } \\
\text { ients }\end{array}$ \\
\hline$\overline{\mathrm{Nil}}$ & 10 & I & 20 & Hernia with & 17 \\
\hline $\mathbf{A}$ & $\begin{array}{l}5 \\
3\end{array}$ & $\begin{array}{l}\text { I-II } \\
\text { II }\end{array}$ & $\begin{array}{l}5 \\
6\end{array}$ & $\begin{array}{l}\text { Stricture } \\
\text { Stricture + }\end{array}$ & $\begin{array}{r}58 \\
0\end{array}$ \\
\hline C & 60 & II-III & $\begin{array}{r}3 \\
18\end{array}$ & $\begin{array}{l}\text { Ulcer } \\
\text { Mucosal } \\
\text { irregularity }\end{array}$ & $\begin{array}{l}3 \\
0\end{array}$ \\
\hline $\begin{array}{l}\text { Total with } \\
\text { oeso- } \\
\text { phagitis }\end{array}$ & 68 & $\begin{array}{c}\text { Total with } \\
\text { oeso- } \\
\text { phagitis }\end{array}$ & 32 & $\begin{array}{l}\text { Total with } \\
\text { oeso- } \\
\text { phagitis }\end{array}$ & 61 \\
\hline $\begin{array}{l}\text { Percentage } \\
\text { oeso- } \\
\text { phagitis }\end{array}$ & $87 \cdot 2$ & $\begin{array}{c}\text { Percentage } \\
\text { oeso- } \\
\text { phagitis }\end{array}$ & $61 \cdot 5$ & $\begin{array}{c}\text { Percentage } \\
\text { oeso- } \\
\text { phagitis }\end{array}$ & $78 \cdot 2$ \\
\hline
\end{tabular}

152 adequate biopsies

of 52 adequate biopsies $(61 \cdot 5 \%)$ and oesophagitis was diagnosed on barium swallow in 61 cases $(78 \cdot 2 \%)$. The incidence of inflammatory disease as determined by these three methods is therefore higher in patients with dysphagia than in any other symptomatic group. There were 10 patients with dysphagia but no endoscopic or radiological evidence of oesophagitis. Two of these had a Schatzki's ring associated with the hiatus hernia and two showed histological inflammation.

4. Bleeding. Five patients had had a previous haematemesis or melaena which, in view of the failure to demonstrate other possible causes, had been attributed to oesophagitis. All five had required blood transfusion. Oesophagoscopy several weeks later demonstrated mild or moderate inflammatory change in two patients and severe oesophagitis in a third. The remaining two cases showed evidence of inflammation on biopsy only.

\section{THE VALUE OF OESOPHAGEAL BIOPSY}

Thirty-five out of $108(32.4 \%)$ biopsies were not adequate for histological grading. These biopsies were evenly distributed throughout the various endoscopic grades of oesophagitis. The incidence of histological inflammation in the 73 adequate biopsies was $56 \cdot 2 \%$. Endoscopic oesophagitis, however, was present in $76.9 \%$ cases, so that the correlation between macroscopic and microscopic findings was only moderately close. Each method of assessment allowed the inflammatory reaction to be graded, and agreement between endoscopic and biopsy grades was reached in 43 of the 73 cases $(58.9 \%)$. In the cases where there was dis- agreement the usual trend was for endoscopy to show severe change and biopsy little or no inflammation.

\section{THE VALUE OF RADIOLOGICAL EXAMINATION}

Oesophagitis was detected in $76.9 \%$ patients at endoscopy but in only $58.3 \%$ cases on radiological examination. This difference was due to failure of cases with mild or moderate endoscopic oesophagitis to show radiological abnormality. There were 62 patients with severe oesophagitis at endoscopy and in $59(95 \%)$ the diagnosis was confirmed by barium swallow. Only 4 of 21 patients with mild or moderate endoscopic change, however, showed diagnostic radiological features of oesophagitis.

In seven patients stricture formation with ulceration was apparent radiologically but endoscopy failed to demonstrate the ulcer because of narrowing of the oesophageal lumen and consequent limitation of view. In six patients the reverse situation occurred; an ulcer was seen at endoscopy but not on barium swallow. This may have been due to shallowness of the ulcer crater.

\section{DISCUSSION}

In this series the incidence or oesophagitis based $\overrightarrow{\overrightarrow{0}}$ on endoscopy was $76.9 \%$. This compares with 3 previous figures of 77\% (Allison, 1951), 24\% (Dagradi and Stempien, 1962), 60\% (Skinner, 1966), and $28.2 \%$ (Palmer, 1968). The wide variation in incidence is at least partly due to patient selection. In the series with a relatively low $\underset{x}{ }$ incidence of oesophagitis, patients were collected $\dot{\sigma}$ from a general gastro-enterology service and some in fact were without oesophageal symptoms. In of our patients and in those reported by Allison (1951), however, symptoms were specific and of 을 sufficient severity to warrant referral for surgical $\rightarrow$ advice. This may explain not only the high overall 을 incidence of oesophagitis in our series, but also the preponderance of severe disease in those $\sigma$ affected.

Oesophagoscopy proved to be the most satis- N factory method of demonstrating oesophagitis 0 except for patients with ulceration and stricture formation, when narrowing of the oesophagus $\stackrel{\odot}{\odot}$ prevented an adequate view of the ulcer in some $\stackrel{\infty}{+}$ instances. This difficulty has also been encountered 0 by Dagradi and Stempien (1962).

Most patients with endoscopic oesophagitis of a mild or moderate grade showed no recognizable $\mathbb{\mathbb { D }}$ abnormality on barium swallow other than a 
sliding hernia with reflux. Radiological examination was more reliable in the severe grades of oesophagitis and $95 \%$ of the strictures seen at endoscopy were demonstrated on barium swallow. The limitations of radiology in the diagnosis of early oesophagitis have been described by several authors (Carver and Sealy, 1954; Johnstone, 1955 ; Edmunds, 1957 ; Palmer, 1968).

Oesophageal biopsy did not prove as valuable as was at first hoped. There was difficulty first of all in obtaining an adequate specimen. Palmer (1955) regarded a biopsy as adequate only if it included the entire thickness of the muscularis mucosae; $39 \%$ of his specimens were unsatisfactory according to this criterion. In our series biopsy material was unsuitable for histological examination in 35 cases $(32.4 \%)$. It is difficult to see how this figure can be improved; overenthusiastic attempts at biopsy could be dangerous and should be avoided.

Histological confirmation of endoscopic oesophagitis was obtained in $62.5 \%$ of cases. Other authors have reported histological inflammation in $72 \%$ (Siegel and Hendrix, 1963), 56\% (Cocco, 1965) and 32.1\% (Schuman and Rinaldo, 1966) of patients with endoscopic change. It is evident, therefore, that there is only moderate agreement between endoscopy and biopsy findings in patients with oesophagitis. In our series this may have been partly due to sampling error, for in some cases the biopsy may have been taken from a relatively unaffected area of oesophagus. A fourquadrant biopsy would prevent this error, though the risks involved in this procedure prohibit its routine use. Schuman and Rinaldo (1966) observed that histological evidence of inflammation was twice as frequent in the herniated stomach pouch as in the oesophagus in patients with endoscopic disease; changes in the gastric pouch have so far received little attention but may provide a closer correlation with clinical symptoms than changes in the oesophagus.

In six patients an inflammatory reaction was found on biopsy although the oesophagus appeared normal at endoscopy. This situation has been observed in several previous studies (Lodge, 1955; Siegel and Hendrix, 1963 ; Schuman and Rinaldo, 1966). One explanation is that inflammatory cells persist in the lamina propria and muscularis mucosae after the acute vascular changes have subsided in patients with intermittent or recurrent oesophagitis. Palmer (1955), however, has suggested that the inflammatory process begins in the lamina propria of the oesophagus and remains largely confined to this layer so that the surface epithelium is either normal or involved to only a minimal extent.

The main symptoms in our patients were pain, heartburn and acid regurgitation, dysphagia and bleeding. Specific retrosternal pain was thought to indicate oesophagitis and in $75 \%$ of patients an inflammatory reaction was observed at endoscopy. Others have reported oesophagitis in $45.4 \%$ (Bernstein and Baker, 1958) and 55.2\% (Dagradi and Stempien, 1962) of patients with this type of pain. The explanation of a negative oesophagoscopy in patients with a history suggestive of oesophagitis may lie in the intermittent nature of the process with subsidence of the acute inflammatory reaction at the time of endoscopy. An alternative explanation is that oesophageal pain in some cases may be due to motor dysfunction rather than to oesophagitis (Dagradi and Stempien, 1962). Although pain was associated with oesophagitis in most patients it was not a common symptom. This is almost certainly due to the high incidence of stricture formation in our series, for a tight stenosis may act as a mechanical barrier to reflux, thereby preventing acute inflammatory exacerbations.

Heartburn and acid regurgitation are common accompaniments of hiatus hernia. They do not in themselves, however, indicate oesophagitis, a fact that has not always been recognized in the past (Edmunds, 1957; Siegel and Hendrix, 1963). An inflammatory reaction was found at endoscopy in $60 \%$ of patients with these symptoms, while Dagradi and Stempien (1962) have reported an incidence of $22.8 \%$ in a similar group. Furthermore, it is well established that patients may present for the first time with severe oesophagitis, having had no previous reflux symptoms (Collis, 1965 ; Skinner, 1966). Heartburn is not therefore synonymous with oesophagitis and in some patients, at least, it may be closely related to motility disturbances (Lazar, Puletti, Douglas, Danovitch, and Texter, 1959 ; Siegel and Hendrix, 1963) or to oesophageal distension (Babey, 1937; Jones, 1938 ; Kramer and Hollander, 1955).

Dysphagia was the commonest symptom in our series and the incidence of endoscopic, histological, and radiological oesophagitis was higher in patients with this symptom than in any other group. Endoscopy failed to demonstrate oesophagitis in 10 patients. Two of these, however, had a Schatzki's ring and two showed histological evidence of inflammation. In the remainder the only detectable pathology was the sliding hiatus hernia. Dysphagia has been described in uncomplicated hiatus hernia in the past, though it is not 
common (Dagradi and Stempien, 1962 ; Palmer, 1968). Reflux induced oesophageal spasm may account for the difficulty in swallowing in these patients.

Bleeding was not a common problem in our patients though it has assumed considerable importance in other series (Dick and Hurst, 1942; Hood and McChesney, 1962; Marchand, 1960). Three of the five patients who bled had endoscopic oesophagitis while the other two showed histological change only. The occurrence of bleeding in the absence of obvious oesophagitis is well recognized (Hood and McChesney, 1962; Windsor and Collis, 1967). Blood loss in these cases may be due to frictional movement of the herniated gastric pouch within the hiatal margins (Windsor and Collis, 1967).

\section{CONCLUSIONS}

1. One hundred and eight patients with sliding hiatus hernias were studied. Oesophagitis was evident at endoscopy in 83 patients $(76.9 \%)$, histological evidence of inflammation was present in 41 out of $73(56.2 \%)$ adequate biopsies and oesophagitis was diagnosed on barium swallow in 63 patients $(58 \cdot 3 \%)$.

2. The main symptoms were pain, heartburn and regurgitation, dysphagia, and bleeding. Dysphagia was common due to the preponderance of patients with stricture formation, while obvious bleeding was uncommon.

3. Endoscopic oesophagitis was found in $75 \%$ of patients with specific retrosternal pain but in only $60 \%$ of those with heartburn and regurgitation. The incidence of inflammatory change in patients with dysphagia was $87.2 \%$; nearly all these cases showed stricture formation.

4. Oesophagoscopy proved to be the most satisfactory method of assessment though in some cases there was difficulty in detecting ulceration in the presence of a stricture.

5. Oesophageal biopsy was not of great value: in one-third of cases the specimen was inadequate and in the remainder correlation with the findings at oesophagoscopy was poor.

6. Radiological examination was accurate in the assessment of severe oesophagitis but was of little diagnostic value in the mild or moderate grades of inflammatory change.

\section{REFERENCES}

Allison, P. R. (1951). Reflux esophagitis, sliding hiatal hernia, and the anatomy of repair. Surg. Gynec. Obstet., $92,419$.

Babey, A. M. (1937). Observations on the nature of heartburn. Amer. J. dig. Dis. Nutr., 4, 600.

Bernstein, L. M., and Baker, L. A. (1958). A clinical test for esophagitis. Gastroenterology, 34, 760.

Carver, G. M., and Sealy, W. C. (1954). Peptic esophagitis. Arch. Surg., 68, 286.

Cocco, A. E. (1965). Endoscopic and biopsy correlation of esophagitis: a review of eighty-four cases. Bull. Gastroint. Fndosc., 11, 29-30.

Collis, J. L. (1965). Benign obstruction of the oesophagus excluding cardiospasm. In Clinical Surgery, Vol. 5, edited by Rob, C., and Smith, R. Butterworths, London.

Dagradi, A. E., and Stempien, S. J. (1962). Symptomatic esophageal hiatus sliding hernia. Clinical, radiologic and endoscopic study of 100 cases. Amer. J. dig. Dis., 7, 613 .

Dick, R. C. S., and Hurst, A. (1942). Chronic peptic ulcer of the oesophagus and its association with congenitally short oesophagus and diaphragmatic hernia. Quart. J. Med., 35 (n.s. 11), 105.

Edmunds, V. (1957). Hiatus hernia. A clinical study of 200 cases. Quart. J. Med., 26, 445.

Hood, R. H., and McChesney, J. A. (1962). Hiatus hernia with esophagitis and acute hemorrhage. J. Amer. med. Ass., 182, 243.

Johnstone, A. S. (1955). Oesophagitis and peptic ulcer of the oesophagus. Brit. J. Radiol., 28, 229.

Jones, C. M. (1938). Digestive Tract Pain: Diagnosis and Treatment. Macmillan, New York.

Kramer, P., and Hollander, W. (1955). Comparison of experimental esophageal pain with clinical pain of angina pectoris and esophageal disease. Gastroenterology, 29, 719.

Lazar, H. P., Puletti, E. J., Douglas, W. W., Danovitch, S., and Texter, E. C. (1959). Nonperistaltic esophageal motility accompanying experimentally produced heartburn. Abstract J. Lab. clin. Med., 54, 917.

Lodge, K. V. (1955). The pathology of non-specific oesophagitis. J. Path. Bact., 69, 17.

Marchand, P. (1960). Hiatus hernia: a cause of gastro-intestinal haemorrhage. Brit. J. Surg., 47, 515.

Palmer, E D. (1955). Subacute erosive ('peptic') esophagitis. Arch. Path., 59, 51.

- (1968). The hiatus hernia-esophagitis-esophageal stricture complex. Amer J. Med., 44, 566.

Schuman, B. M., and Rinaldo, J. A. (1966). Relative frequency of esophagitis and gastritis in patients with symptomatic hiatus hernia. Gastroint. Endosc., 12, 14-16.

Siegel, C. I., and Hendrix, T. R. (1963). Esophageal motor abnormalities induced by acid perfusion in patients with heartburn. J. clin. Invest., 42, 686 .

Skinner, D. B. (1966). Symptomatic esophageal reflux. Amer. J. dig. Dis., 11, 771.

Windsor, C. W. O., and Collis, J. L. (1967). Anaemia and hiatus hernia: experience in 450 patients. Thorax, 22, 73. 